Revista Brasil. Bot., V.28, n.4, p.765-772, out.-dez. 2005

\title{
Juvenile dynamics of the endemic and rare Enterolobium glaziovii Benth. (Mimosaceae) around reproductive trees in the Atlantic forest, Brazil
}

\author{
FLAVIO N. RAMOS ${ }^{1,4}$, DALVA M. SILVA-MATOS ${ }^{2}$ and FLAVIO A. MAËS DOS SANTOS ${ }^{3}$
}

(received: October 7, 2004; accepted: October 26, 2005)

\begin{abstract}
ABTRACT - (Juvenile dynamics of the endemic and rare Enterolobium glaziovii Benth. (Mimosaceae) around reproductive trees in the Atlantic Forest, Brazil). Studies on the regeneration and seedling mortality of rare tree species are important, but scarce. The aim of this study was to investigate the annual variation in recruitment, growth and mortality of juveniles of Enterolobium glaziovii Benth., a rare tree species from the Brazilian Atlantic Rain Forest. All seedlings and juveniles around four reproductive trees were labeled and their fate was followed from 1996 to 1999 . There were no annual differences in juveniles' recruitment below and beyond the parental crown, but juveniles' survival and growth were lower below than beyond of the parental tree crowns. Small individuals $(<15 \mathrm{~cm}$ tall) showed the greatest mortality and the lowest growth, followed by medium (from 15 to $50 \mathrm{~cm}$ tall) and large ones (>50 cm tall). Large juveniles were more widely dispersed from the conspecific parental tree than were medium and small ones. This suggests that distance dependent mortality of juveniles mediated by the parental tree is an important cause of spacing shifts associated with the growth of small individuals of E. glaziovii into large ones. Widely dispersed juveniles may escape the high mortality associated with pathogens, herbivores or seed predators concentrated around adult conspecifics. The negative influence of the parental tree on its juveniles may explain the sparse distribution of its adults in the forest.
\end{abstract}

Key words - conspecific influence, distance-dependent mortality, growth, shade tolerance, size-dependent mortality

RESUMO - (Dinâmica de juvenis do raro e endêmico Enterolobium glaziovii Benth. (Mimosaceae) ao redor de individuos reprodutivos na Mata Atlântica, Brasil). Estudos sobre regeneração e mortalidade de plântula de espécies de árvores raras são importantes, porém escassos. O objetivo deste estudo foi investigar a variação anual no recrutamento, crescimento e mortalidade de juvenis de Enterolobium glaziovii Benth., uma espécies de árvore rara da mata Atlântica. Todas as plântulas e juvenis ao redor de quatro árvores reprodutivas foram marcadas e acompanhadas de 1996 a 1999. Não houve variações anuais no recrutamento de juvenis embaixo ou fora da copa da árvore parental, mas a sobrevivência e crescimento dos juvenis foram menores embaixo do que fora da copa da planta parental. Indivíduos pequenos $(<15 \mathrm{~cm}$ de altura) apresentaram maior mortalidade e menor crescimento, seguidos pelos indivíduos médios (entre 15 e $50 \mathrm{~cm}$ de altura) e grandes $(>50 \mathrm{~cm}$ de altura). Indivíduos grandes estavam mais afastados do indivíduo parental do que os médios e pequenos. Estes resultados sugerem que a mortalidade dependente de distância de juvenis, mediada pelas árvores parentais, é uma das mais importantes causas de mudanças espaciais associadas com o crescimento de indivíduos pequenos de E. glaziovii a indivíduos grandes. Os juvenis com maior distância dos adultos podem escapar da alta mortalidade associada com patógenos, herbívoros ou predadores de sementes concentrados ao redor de adultos coespecíficos. A influência negativa da planta parental sobre os juvenis pode explicar a distribuição esparsa dos adultos desta espécies na floresta.

Palavras-chave - crescimento, influência do coespecífico, mortalidade dependente de distância, mortalidade dependente de tamanho, tolerância ao sombreamento

\section{Introduction}

It is widely known that one of the most threatened tropical forest ecosystems in the world is the Brazilian

1. Universidade Estadual de Campinas, Instituto de Biologia, Programa de Pós-Graduação em Ecologia, Caixa Postal 6109, 13083-970 Campinas, SP, Brazil.

2. Universidade do Rio de Janeiro, Departamento de Ciências Naturais, Av. Pasteur 458, 22290-240 Rio de Janeiro, RJ, Brazil.

3. Universidade Estadual de Campinas, Instituto de Biologia, Departamento de Botânica, Caixa Postal 6109, 13083-970 Campinas, SP, Brazil.

4. Corresponding author: fnramos@gmail.com
Atlantic Forest, which extends along the Brazilian coast, where the largest part of that country's population and economics activities are located (Mori et al. 1981). The Atlantic forest of Brazil, like other tropical forests (Richards 1996), contains a large number of rare plant species that are more prone to extinction by forest fragmentation, because of the isolation and decline of their population size (Alvarez-Buylla et al. 1996). There is, however, very little information about these species, particularly regarding ecological aspects that may be useful in management projects. Tree regeneration is an important phenomenon that has received little attention. 
Its comprises recruitment, survivorship, and the growth of a very large number of species that may differ in their mode of life and in regeneration, (Laurance et al. 1998).

Studies from Costa Rica (Condit et al. 1992) and Brazil (Silva-Matos et al. 1999) have shown that the regeneration of common tree species is the only population process regulated by density factors, with the mortality of seedlings and juveniles increasing as the density of conspecifics increases. However, for many species, regeneration is affected by the parental tree (Chapman \& Chapman 1995) through the action of seed predators, herbivores or pathogens (Janzen 1970, Connell 1971, Silva-Matos \& Watkinson 1998). For example, De Steven (1994) revealed that first year seedlings of three shade tolerant canopy species had relatively low survival over the subsequent years compared to older seedlings and saplings.

Tree regeneration may vary amongst years because of natural climatic changes in the forest (Garwood 1982). Large fluctuations in soil water availability, for example, may be detrimental or even lethal for seedling emergence and survival (Augspurger 1979). The timing of recruitment could affect both the likelihood of suffering environmental stress such as drought, and the prospects of competition from pre-existing seedlings (Garwood 1982). Thus, changes in natural climate among years could increase or decrease the influence of parental tree on juvenile regeneration.

Therefore, the goals of this study were to investigate the annual variation in the recruitment, growth and mortality of Enterolobium glaziovii Benth. juveniles around reproductive trees. Long-term studies on tree regeneration are rare (Sarukhán 1978, Hubbell et al. 1990, Hubbell \& Foster 1992, Alvarez-Buylla 1994, De Steven 1994, Silva-Matos \& Watkinson 1998, SilvaMatos et al. 1999), and most studies of tropical tree seedlings have been restricted to periods of 1-2 years. Studies of regeneration in rare tree species, as well as a knowledge of the factors that influence seedling mortality, which is very high (Clark \& Clark 1985), can lead to a better understanding of the process of tree regeneration, and has practical applications in the management of forests (Still 1996). Enterolobium glaziovii (Mimosaceae) is a rare canopy tree endemic to Brazilian coastal Atlantic forests, with the adults often located very far from each other (at least $2 \mathrm{~km}$ ) (personal observation).

The questions addressed here were: 1) are there annual differences in juvenile recruitment, mortality and growth below and beyond the parental crown? 2) are there differences in the growth and mortality among juveniles of different sizes?, and 3) does seedling growth vary with the level of shade? Variations in species response to irradiance are very important, particularly since canopy coverage can change through natural tree fall, logging and other disturbances that affect the new individuals stabling chances (Swaine et al. 1997, Agyeman et al. 1999). The seedlings ability to grow and survive in the understory, where light may often be limiting, is one of the conditions for successful tree regeneration in this environment (Brokaw 1985, Hubbell \& Foster 1990, Poorter 1999). The few seedlings that survive in the understory are very important in forest dynamics because suppressed seedlings and saplings are a major component of the regrowth that occurs in new treefall gaps (Brokaw 1985). Moreover, the relationship between light conditions and tree growth can serve to predict future timber yields in managed forests using an individualbased growth model (Webb 1999).

\section{Material and methods}

Study species - Enterolobium (Mimosaceae) is a neotropical genus distributed from Central America (Mexico) to South America (Argentina), being Amazon its diversity center (Mesquita 1990). The timber of this genus is used to make boats, packing cases and scantlings. Enterolobium species are distinguished mainly by their fruit morphology, which is predominantly indehiscent. Among the 10 species of the genus, E. glaziovii Benth. has a restricted geographic distribution having been reported from only three states in Brazil (Rio de Janeiro, Espirito Santo and Bahia), and is therefore endemic of the Brazilian coastal Atlantic forests (Mesquita 1990). This species, which occurs at a low frequency in the forest (H.C. Lima unpublished data), is a deciduous canopy tree, and reproductive individuals range from 8 to $30 \mathrm{~m}$ tall (Mesquita 1990). The fruits are large and heavy (14.6 $\mathrm{g} \pm 6.4$, mean $\pm \mathrm{sd})$, and are contorted black woody pods $(8-10 \mathrm{~cm} \times 4-5 \mathrm{~cm})$ that contain 1 to 14 seeds, with a mean of nine seeds per fruit (F.N. Ramos \& A.C.S. Andrade, unpublished data). The seeds of some Enterolobium species are dispersed by tapirs and rodents (Janzen 1981, Fragoso \& Huffman 2000). All E. glaziovii juveniles occur in environments with canopy coverage $>80 \%$ (F.N. Ramos \& F.A.M Santos unpublished data).

Study areas - The study was carried out in four circular plots with $30 \mathrm{~m}$ radius (three times the mean radius of the crown of the reproductive trees), each one centered on a reproductive tree of E. glaziovii. Three (B1, B2, and B3) were located in the Biological Reserve of Poço das Antas (BIORE) (22 $29^{\prime}-22^{\circ} 36^{\prime} \mathrm{S}$ and $42^{\circ} 13^{\prime}-42^{\circ} 21^{\prime} \mathrm{W}$ ), while the fourth (R1) was in the Tijuca National Park, close to the Rio de Janeiro Botanical Garden (RJBG) (22 $58^{\prime}$ S and $\left.43^{\circ} 13^{\prime} \mathrm{W}\right)$ in Rio de Janeiro State, Brazil. Both areas are in the Atlantic Forest, which is evergreen, or dense 
ombrophilous (sensu Velloso et al. 1991). At BIORE, the mean temperature is $27.6^{\circ} \mathrm{C}$ in summer and $21.3^{\circ} \mathrm{C}$ in winter, and the mean annual rainfall is $2091.9 \mathrm{~mm}$ (IBDF 1981a and data from the Golden Lion Tamarin Association obtained from 1983 to 1998). At the RJBG, the mean temperature is $29^{\circ} \mathrm{C}$ in summer and $22^{\circ} \mathrm{C}$ in winter, with a mean annual rainfall of $1,075 \mathrm{~mm}$ (IBDF 1981b, Coelho Neto 1985 apud Oliveira \& Lacerda 1988). Only four reproductive trees were found in both areas and all were isolated. The distance between the BIORE and RJBG is $126 \mathrm{~km}$ and within BIORE the distance between individuals ranged from 2.5 to $10 \mathrm{~km}$. Each plot was considered as a replicate, regardless of the climatic differences.

Recruitment, growth and mortality - All E. glaziovii juveniles (non-reproductive individuals) in the circular plots were tagged and their location below and beyond the central reproductive tree crown was recorded. The survival of the juveniles, the presence of new recruits (small individuals that were absent in preceding census) and their height (from the ground to the apical bud) were recorded annually from 1996 to 1999. Mortality was defined as death or disappearance, whereas stems that had snapped but resprouted were considered alive.

Juvenile size classes - To assess whether mortality was size dependent, juveniles of the 1996 cohort were divided in three size classes: small $(<15 \mathrm{~cm}$ tall), medium (from 15 to $50 \mathrm{~cm}$ tall) and large ( $>50 \mathrm{~cm}$ tall). The juvenile size classes were visually selected after analyzed their total height range.

Shade levels - The response of E. glaziovii seedlings to different levels of shade was examined in a greenhouse experiment done at the Universidade Estadual de Campinas, São Paulo State, Brazil. Seeds were scarified and placed in plastic pots on vermiculite, with no light or temperature control. When the seedling radicle reached $3 \mathrm{~mm}$, the seedlings were individually planted in $500 \mathrm{ml}$ plastic cups filled with a 2:1 soil:sand mixture. The phaneroepigeal seedlings (sensu Garwood 1996) were initially grown in the greenhouse. After the cotyledons had completely expanded, the seedlings were transferred to boxes covered with thin plastic shade cloth, which limited the light incidence in $90 \%, 80 \%, 60 \%, 40 \%$, and $0 \%$. The irradiance in each box was measured with an LI-COR quantum sensor coupled to a LI 1000 data logger. Concurrent measurements were made inside each box and in an open area at 12:00 $\mathrm{h}$ on four cloudless days, so that the treatments could be expressed as the percentage of shade.

Twenty seedlings per treatment were randomly placed in five rows of four plastic cups in each box and were rerandomized every month throughout the six-month experiment. The seedlings were watered daily and their height (up to the apical meristem) and root collar diameter were recorded monthly. Twenty seedlings were harvested, at the beginning of the experiment, and the remainder were harvested at the end of the experiment. The leaves, stems and roots of the harvested seedlings were dried at $80^{\circ} \mathrm{C}$ for $48 \mathrm{~h}$, prior to dry biomass measurements was obtained. The relative leaf mass (RLM) and relative root mass (RRM) (dry mass of leaves or roots / total seedling dry mass) were calculated for each seedling according to Hunt (1982). Stem robustness (SR) (total dry mass / stem length) was calculated according to Lee et al. (1996).

Statistical analysis - The mean annual recruitment rates, $r$, were estimated as follows (Sheil \& May 1996, Burslem et al. 2000): $r=1-(1-\mathrm{nr}-\mathrm{Nt})^{1 / t}$; where $\mathrm{nr}$ is the number of recruits and $\mathrm{Nt}$ is the number of juveniles present at the end of the measurement interval $t$. This formula provides recruitment rate estimates that are equivalent in form to mortality rate estimates (Burslem et al. 2000).

The mean annual mortality rates, $m$, were calculated using to the following equation (Sheil et al. 1995, Burslem et al. 2000): $m=1-\left(1-\left(\mathrm{N}_{0}-\mathrm{N}_{1}\right) / \mathrm{N}_{0}\right)^{1 / t}$; where $\mathrm{N}_{0}$ and $\mathrm{N}_{1}$ are the number of juveniles at the beginning and end of the time interval $(t=1$ year $)$. This measure of mortality is derived from an exponential model of population decline and assumes a constant probability of mortality during interval $t$.

The annual differences in juvenile recruitment and growth below and beyond the parental crown were analyzed using two-way ANOVA, with year and location (below and beyond the central reproductive tree crown) as fixed effects. The differences in growth, mortality rate and distance from the E. glaziovii parental tree among juveniles of different sizes were assessed by two-way ANOVA, with fixed effects for year and juvenile size classes (small, medium and large). one-way ANOVA was used to compare the seedling growth under different levels of shade. To improve homocedasticity and normality of the distributions, the data for recruitment and the mortality and growth rates were log transformed (Zar 1996). Systat (Wilkinson 1997) was used to data analyses.

\section{Results}

Characteristics of parental trees and juveniles - Parental tree height ranged from 18 to $24 \mathrm{~m}$, while the crown radius ranged from 1.0 to $15.3 \mathrm{~m}$ with an area of 61.8 to $373.2 \mathrm{~m}^{2}$, the latter corresponding to $2.2-13.2 \%$ of the total plot area. The height of E. glaziovii individuals with and without cotyledons ranged from 1.8 to $11.4 \mathrm{~cm}$ and 11.5 to $480 \mathrm{~cm}$, respectively. The cotyledons took from 1 to 60 days to fall, according to laboratory observations. The total number of juveniles below the central reproductive tree crown ranged from 10 to 113 , while it varied from 1 to 80 beyond it. The distance between the juveniles and the parental tree varied from 0.1 to $28 \mathrm{~m}$. Additionally seeds of E. glaziovii germinated throughout the year (data not shown).

Recruitment, growth and mortality - The yearly recruitment of new juveniles was low (figure 1A), with no annual $\left(\mathrm{F}_{2,18}=0.58 ; \mathrm{p}=0.57\right)$ differences in the recruitment rates of juvenile below and beyond the 
parental crown $\left(\mathrm{F}_{1,18}=0.40 ; \mathrm{p}=0.53\right)$. However, there were differences in juvenile mortality $\left(\mathrm{F}_{1,18}=6.2\right.$; $\mathrm{p}=0.02)$ and growth $\left(\mathrm{F}_{1,18}=3.89 ; \mathrm{p}=0.049\right)$ between locations but not among years $\left(\mathrm{F}_{2,18}=2.5 ; \mathrm{p}=0.11\right.$ for juvenile mortality and $\mathrm{F}_{2,18}=0.78 ; \mathrm{p}=0.46$ for growth). Although the annual juvenile mortality was very low (figure 1B), there was a higher probability of juvenile mortality below than beyond the central reproductive tree crown. In contrast, there was more height increment on juvenile beyond the central reproductive tree crown than below it (figure 1C).
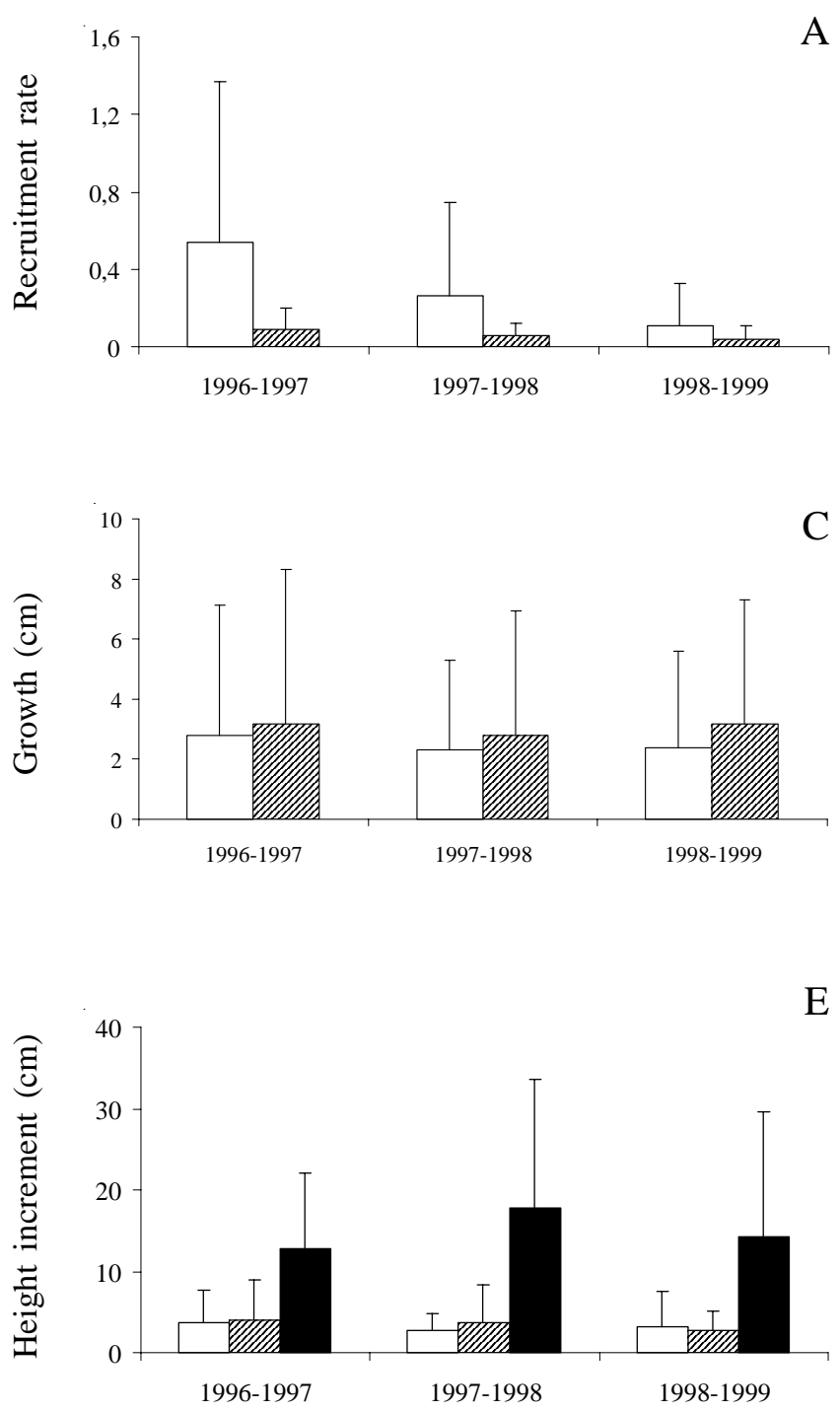

E
Juvenile size classes - There were significant differences in mortality and growth rates within juvenile size classes $\left(\mathrm{F}_{2,27}=6.0 ; \mathrm{p}=0.007\right.$ and $\mathrm{F}_{2,379}=28.75 ; \mathrm{p}=0.001$, respectively $)$ but no differences among years $\left(\mathrm{F}_{2,27}=0.3\right.$; $\mathrm{p}=0.69$ and $\mathrm{F}_{2,379}=1.03 ; \mathrm{p}=0.36$, respectively). Larger juveniles $(>50 \mathrm{~cm})$ had a significantly lower mortality rate (figure 1D) and a greater increase in height (figure 1E) than small $(<15 \mathrm{~cm})$ and medium (between 15 and $50 \mathrm{~cm}$ ) juveniles.

There were also differences in the distance from the parental tree among the juvenile size classes
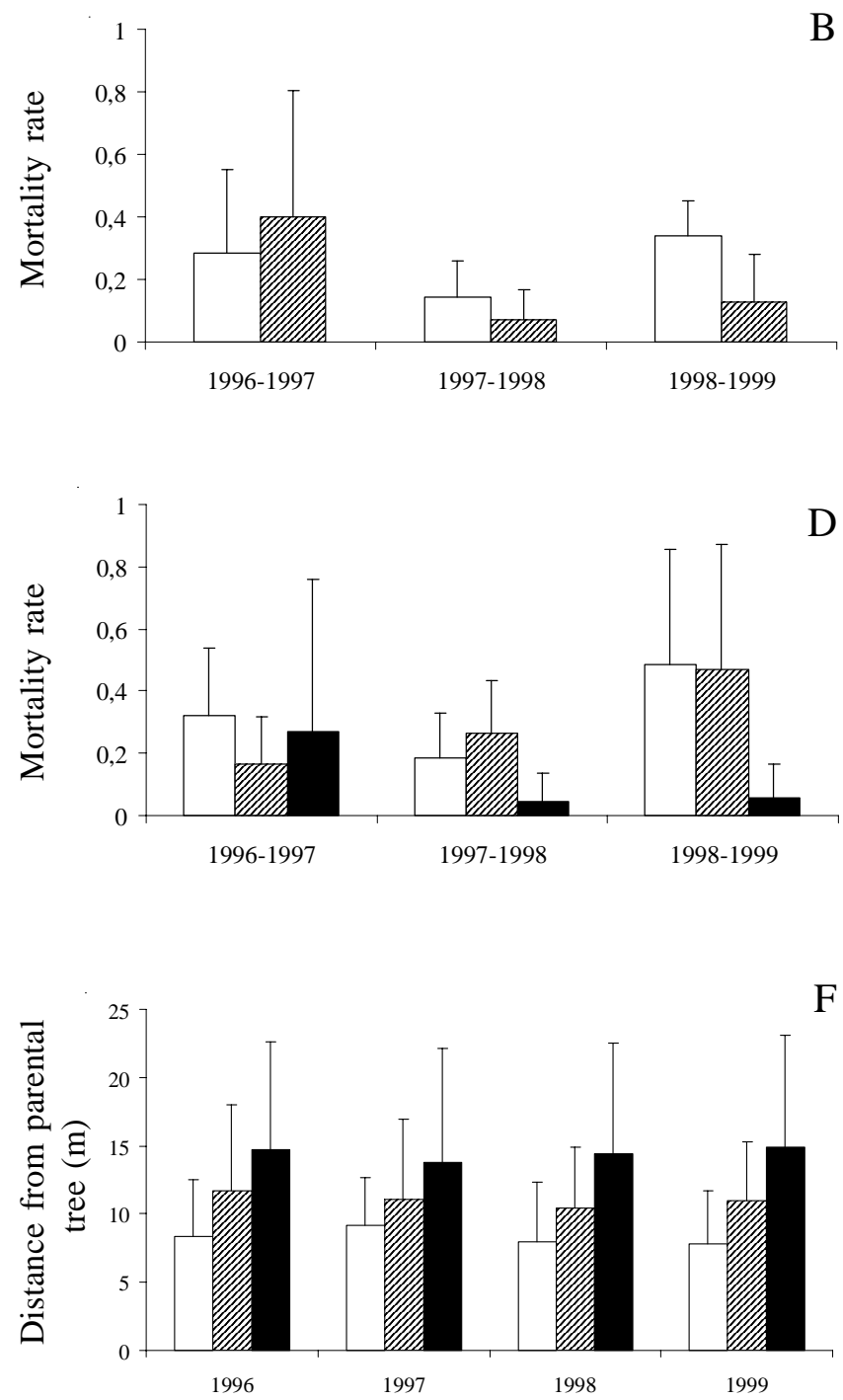

Figure 1. Recruitment rate (mean \pm SD) $(A)$, mortality rate (mean \pm SD) $(B)$, and growth (height increment) (mean \pm SD) $(C)$ of E. glaziovii offspring under (dotted bars) and out of (hatched bars) the central reproductive tree crown of E. glaziovii trees in Atlantic forest sites, among years (date were back transformed). Additionally mortality rate (D), height increment (cm) (E) of E. glaziovii offspring (mean \pm SD) and in each size class: small $(<15 \mathrm{~cm}$ tall) $(\square)$, medium $(15$ to $50 \mathrm{~cm}$ tall) $(\square)$ and large $(>50 \mathrm{~cm}$ tall) individuals ( $\mathbf{\square})$, and the distance $(\mathrm{F})$ of each size class from E. glaziovii parental tree in Atlantic forest sites among years (date were back transformed). Large individuals presented significant lower mortality rate and greater height increment than the other two size classes. The three distance classes were significantly different from each other. 
$\left(\mathrm{F}_{2,819}=53.4 ; \mathrm{p}=0.001\right)$, but not among years $\left(\mathrm{F}_{3,819}=0.36 ; \mathrm{p}=0.78\right)$. Larger juveniles $(>50 \mathrm{~cm})$ occurred at significantly greater distances from the parental trees, followed by medium $(15-50 \mathrm{~cm})$ and small $(<15 \mathrm{~cm})$ individuals (figure $1 \mathrm{~F})$.

Shade levels - After 65 days, no E. glaziovii seedlings in the greenhouse had cotyledons. Enterolobium glaziovii survived and grew under all shade treatments, but there were differences in growth. The seedlings in $90 \%$ and $80 \%$ of shade were significantly taller than in the other treatments $\left(\mathrm{F}_{4,88}=11.4 ; \mathrm{p}=0.001\right)$, although there was no significant difference in stem diameter growth among treatment $\left(\mathrm{F}_{4,88}=0.37 ; \mathrm{p}=0.83\right)$. There were differences in stem robustness among the treatments $\left(\mathrm{F}_{4,88}=10.0 ; \mathrm{p}=0.004\right)$, except for seedlings in $90 \%$ and $0 \%$ treatments. Thus, seedlings in $90 \%$ shade were not etiolated, although they showed the greatest growth in height, and the total dry mass of those seedlings was not different from that of the other shade treatments. Seedlings in all treatments produced similar total biomass $\left(\mathrm{F}_{4,88}=1.47 ; \mathrm{p}=0.21\right)$. The allocation of biomass to the roots $(\mathrm{RRM})\left(\mathrm{F}_{4,88}=9.0 ; \mathrm{p}=0.001\right)$ and leaves $(\mathrm{RLM})$ $\left(\mathrm{F}_{4,88}=4.9 ; \mathrm{p}=0.001\right)$ differed among the treatments (table 1). The seedlings under $0 \%$ shade had a greater relative root mass (RRM), whereas seedlings under $90 \%$ shade had greater relative leaf mass (RLM) than those in the other treatments (table 1).

\section{Discussion}

Table 1. Means height $(\mathrm{cm})$, collar diameter $(\mathrm{cm})$, total dry mass (g) (TDM), root mass ratio (g) (RMR), leaf mass ratio (g) (LMR) and stem robustness $\left(\mathrm{g} \mathrm{g}^{-1}\right)(\mathrm{SR})$ of E. glaziovii in each shade treatment. In each row, different letters regard statistical difference of $5 \%$ of significance on the one-way ANOVA.

\begin{tabular}{lrrrrr}
\hline & $90 \%$ & $80 \%$ & $60 \%$ & $40 \%$ & $0 \%$ \\
\hline Height & $4.1^{\mathrm{b}}$ & $3.9^{\mathrm{b}}$ & $2.6^{\mathrm{a}}$ & $2.6^{\mathrm{a}}$ & $2.5^{\mathrm{a}}$ \\
Diameter & $0.10^{\mathrm{a}}$ & $0.12^{\mathrm{a}}$ & $0.10^{\mathrm{a}}$ & $0.11^{\mathrm{a}}$ & $0.09^{\mathrm{a}}$ \\
TDM & $0.53^{\mathrm{a}}$ & $0.61^{\mathrm{a}}$ & $0.58^{\mathrm{a}}$ & $0.54^{\mathrm{a}}$ & $0.44^{\mathrm{a}}$ \\
RRM & $0.40^{\mathrm{a}}$ & $0.38^{\mathrm{a}}$ & $0.42^{\mathrm{a}}$ & $0.47^{\mathrm{ab}}$ & $0.51^{\mathrm{b}}$ \\
RLM & $0.46^{\mathrm{b}}$ & $0.49^{\mathrm{b}}$ & $0.46^{\mathrm{ab}}$ & $0.42^{\mathrm{ab}}$ & $0.38^{\mathrm{a}}$ \\
SR & $0.009^{\mathrm{a}}$ & $0.009^{\mathrm{ab}}$ & $0.010^{\mathrm{b}}$ & $0.011^{\mathrm{b}}$ & $0.008^{\mathrm{a}}$ \\
\hline
\end{tabular}

Rain forest tree species are often classified into two functional groups based on their germination and establishment requirements (Swaine \& Whitmore 1988). Shade-tolerant species can germinate, grow and survive in environments of low light intensity, whereas light demanding species need an environment with a high light intensity in order to establish (Poorter 1999). Shadetolerant species constitute the vast majority of tropical forest tree species (Welden et al. 1991). In a rain forest in Panama, for example, saplings of $79 \%$ of the species were shade-tolerant (Welden et al. 1991). Enterolobium glaziovii presents the characteristics of a shade-tolerant, "non-gap" species, since it is capable of germinating (F.N. Ramos \& A.C.S. Andrade, unpublished data) and growing in environments with a low light intensity. In contrast to many leguminous species with dormant seeds (Vazquez-Yanes \& Orozco-Segovia 1984), E. glaziovii germination is not dependent on environmental conditions, such as alternating temperature associated with canopy disturbance.

Seedlings of E. glaziovii under greenhouse conditions grew under a broad range of shade levels. However, they presented traits of shade-tolerant species, such as higher growth under $90 \%$ and $80 \%$ shade, but without etiolation. According to Crawford (1989), shade plants can maintain a constant growth under light intensities that range from full sun to moderate shade. Consequently, shade tolerance in these species is not related to growth but to persistence (Paccala et al. 1996), and these species do not maximize their potential growth rate, but rather their realized biomass growth under field conditions (Kitajima 1996 apud Poorter 1999).

The differential biomass allocation of sun vs. shade seedlings is expected in plants growing in different light environments (Agyeman et al. 1999). Plants grown under shade tend to enhance their light interception by directing a higher biomass allocation to their leaves (Crawford 1989). According to our results, E. glaziovii juveniles do not need large or medium size gaps, but can grow and survive in light environments created by fall of debris or trees. Thus, these plants invest more in root mass and could compensate for higher transpiration losses by increasing their water uptake (Veenendaal et al. 1996).

Although E. glaziovii seedlings survived under $0 \%$ shade (full sun) in the greenhouse experiment, no individuals were found under similar conditions at any of the forest sites around the parental trees. This may indicate that other environmental variables are also important factors in influencing juvenile growth. Root competition, for example, could also influence the growth and survival of tree seedlings (Denslow et al. 1991). According to Swaine et al. (1997), the response of juveniles to irradiance in a greenhouse may be modified by mycorrhizal infection and by the success with which plant roots explore the soil resources and harvest 
nutrients in the presence of competing species at forest sites.

In this study, E. glaziovii followed a welldocumented general pattern of size-dependent survivorship in tree populations (Gilbert et al. 2001), with small individuals experiencing the greatest mortality and the lowest growth. This early phase is apparently a critical period for E. glaziovii since, if small individuals surpass this threshold, their chances of survival will increase. Large juveniles of E. glaziovii were more widely dispersed from conspecific parental trees than were medium and small ones. This suggests that distancedependent mortality of juveniles is an important factor leading to significant spacing shifts, with the growth of small individuals of E. glaziovii into large ones. Widely dispersed juveniles may escape high mortality due to pathogens, herbivores (Clark \& Clark 1985) or seed predators concentrated around adult conspecifics, although further study is needed to identify specific agents.

Recruitment of E. glaziovii was not different below and beyond the parental tree crown. Condit et al. (1992) analyzed the sapling recruitment of about 80 species of trees and shrubs and showed that only the two or three most common species had a decreased recruitment near conspecific adults, most of the tree species studied presented no clear pattern of recruitment in the vicinity of large conspecifics. In contrast to recruitment, the survival and growth of E. glaziovii juveniles were lower below than beyond of parental tree crown. Evidence of escape from mortality agents associated with adults has been documented in several studies (Wada \& Ribbens 1997, Gilbert et al. 2001). Long-term demographic studies on Barro Colorado Island have shown that the growth and survival of juveniles commonly are negatively affected when the juveniles grow below a conspecific adult (Hubbell \& Foster 1990). These authors also showed that the decrease in the survival and growth rate of juveniles of rare tree species below conspecific adults versus below heterospecific large trees were greater for rare species than for common ones (1.6 and 1.3 fold, respectively). Although we do not know whether pests or pathogens were important in the juvenile mortality for E. glaziovii during our study, these factors are important for several species in tropical forests (Gilbert et al. 1994).

Despite the low quantity of parental trees, we can conclude that the spatial pattern of recruitment of E. glaziovi is related to fruit and/or seed dispersal because its seeds do not require specific conditions to germinate, such as light or alternating temperature (F.N. Ramos \&
A.C.S. Andrade, unpublished data). Although there was no difference between the recruitment below and beyond the parental tree crown, there were more fruits and juveniles below adult tree crowns. Seedlings of this species were able to survive and grow under a broad range of shade levels, but the probability of survival and growth was lower below than beyond the parental tree crown. The annual consistency of the distance dependent pattern of juvenile distribution may explain the very sparse occurence of E. glaziovii adults in natural forest.

Acknowledgements - The authors thank A.F. Souzas, M.C. Torres, J.F. Caluca, L.P. Siqueira, R.C.Q. Portela, M.I.G. Braz, L.S. Lima, T.B. Quental, J.L. Nascimento, J.L.S. Neto and A.M. Rosa for valuable help in the field work, and A.A. Oliveira, F.R. Martins, G.M.S. Ganade and M.T. Nascimento for their comments on the manuscript. The Golden Lion Tamarin Association provided data on the rainfall and temperature of the Poço das Antas Biological Reserve. This work was supported by the Fundação de Amparo à Pesquisa do Estado de São Paulo, grant n ${ }^{\circ}$ 98/01264-0.

\section{References}

AGYEMAN, V.K., SWAINE, M.D. \& THOMPSON, J. 1999. Responses of tropical forest tree seedlings to irradiance and the derivation of a light response index. Journal of Ecology 87:815-827.

ALVAREZ-BUYLLA, E.R. 1994. Density dependence and patch dynamics in tropical rain forests: matrix models and applications to a tree species. American Naturalist 143:155-191.

ALVAREZ-BUYLLA, E.R., GARCIA-BARRIOS, R., LARAMORENO, C. \& MARTINEZ-RAMOS, M. 1996. Demographic and genetic models in conservation biology: applications and perspectives for tropical rain forest tree species. Annual Review of Ecology and Systematics 27:387-421.

AUGSPURGER, C.K. 1979. Irregular rain cues and the germination and seedling survival of a Panamanian shrub (Hybanthus prunifolius). Oecologia 44:53-59.

BROKAW, N.V.L. 1985. Gap-phase regeneration in a tropical forest. Ecology 66:682-687.

BURSLEM, D.F.R.P., WHITMORE, T.C. \& BROWN, G.C. 2000. Short-term effect of cyclone impact and long-term recovery of tropical rain forest on Kolombangara, Solomon Island. Journal of Ecology 88:1063-1078.

CHAPMAN, C.A. \& CHAPMAN, L.J. 1995. Survival without dispersers: seedling recruitment under parents. Conservation Biology 9:675-678

CLARK, D.B. \& CLARK, D.A. 1985. Seedling dynamics of a tropical tree: impacts of herbivory and meristem damage. Ecology 66:1884-1892. 
CONDIT, R., HUBBELL, S.P. \& FOSTER, R.B. 1992. Recruitment near conspecific adults and the maintenance of tree and shrub diversity in a neotropical forest. American Naturalist 140:261-286.

CONNELL, J.H. 1971. On the role of natural enemies in preventing competitive exclusion in some marine animals and in rain forest trees. In Dynamics of populations (P.J. Den Boer \& G. Gradwell, eds.). PUDOC, Wageningen, p.298-310.

CRAWFORD, R.M.M. 1989. Studies in plant survival: ecological case histories of plant adaptation to adversity. Blackwell Scientific Publications, Oxford.

DENSLOW, J.S., NEWELL, E. \& ELLISON, A.M. 1991. The effect of understory palms and cyclanths on the growth and survival of Inga seedlings. Biotropica 23:225-234.

DE STEVEN, D. 1994. Tropical tree seedling dynamics: recruitment patterns and their population consequences for three canopy species in Panama. Journal of Tropical Ecology 10:369-383.

FRAGOSO, J.M.V. \& HUFFMAN, J.M. 2000. Seed-dispersal and seedling recruitment patterns by the last Neotropical megafaunal element in Amazonia, the tapir. Journal of Tropical Ecology 16:369-385.

GARWOOD, N. 1982. Seasonal rhythm of seed germination in a semideciduous tropical forest. In The ecology of a tropical forest: seasonal rhythms and long-term changes. (E.G. Leigh, A.S. Rand \& D.M. Windsor, eds.). Smithsonian Institution Press, Washington, p.173-186.

GARWOOD, N.C. 1996. Functional morphology of tropical tree seedlings. In Ecology of tropical forest tree seedlings (M.D. Swaine, ed.). Unesco/Pathernon, Paris/Carnforth, p.59-130.

GILBERT, G.S., HUBBELL, S.P. \& FOSTER, R.B. 1994. Density and distance dependence to adult effects of a canker disease of trees in a moist tropical forest. Oecologia 98:100-108.

GILBERT, G.S., HARMAS, K.E., HAMILL, D.M. \& HUBBELL, S.P. 2001. Effects of seedling size, El Niño drought, seedling density, and distance to nearest conspecific adult on 6-year survival of Ocotea whitei seedlings in Panama. Oecologia 127:509-516.

HUBBELL, S.P. \& FOSTER, R.B. 1990. The fate of juvenile trees in a neotropical forest: implications for the natural maintenance of tropical tree diversity. In Reproductive ecology of tropical forest plants (K.S. Bawa \& M. Hadley, eds.). Unesco/Pathernon, Paris/Carnforth, p.267-283.

HUBBELL, S.P. \& FOSTER, R.B. 1992. Short-term dynamics of a neotropical forest - why ecological research matters to tropical conservation and management. Oikos 63:48-61.

HUBBELL, S.P., CONDIT, R. \& FOSTER, R.B. 1990. Presence and absence of density dependence in a neotropical tree community. Philosophical Transactions of the Royal Society of London - B 330:269-281.

HUNT, R. 1982. Plant growth curves. Edward Arnold Publisher, London.
IBDF. 1981a. Plano de manejo da Reserva Biológica de Poço das Antas. Ministério do Meio Ambiente, Brasília.

IBDF. 1981b. Plano de manejo do Parque Nacional da Tijuca. Ministério do Meio Ambiente, Brasília.

JANZEN, D.H. 1970. Herbivores and the number of tree species in tropical forests. American Naturalist 104:501-528.

JANZEN, D.H. 1981. Enterolobium cyclocarpum seed passage rate and survival in horses, costa-rican pleistocene seed dispersal agents. Ecology 62:593-601.

LAURANCE, W.F., FERREIRA, L.V., RANKIN-DE-MERONA, J.M., LAURANCE, S.G., HUTCHINGS, R.W. \& LOVEJOY, T.E. 1998. Effects of forest fragmentation on recruitment patterns in Amazonian tree communities. Conservation Biology 12:460-464.

LEE, D.W., BASKARAN, K., MANSOR, M., MOHAMAD, H. \& YAP, S.K. 1996. Irradiance and spectral quality affect Asian tropical rain forest tree seedling development. Ecology 77:568-580.

MESQUITA, L.M. 1990. Revisão taxonômica do gênero Enterolobium Mart. (Mimosoidea). Dissertação de mestrado, Universidade Federal Rural de Pernambuco, Recife.

MORI, S.A., BOOM, B.M. \& PRANCE, G.T. 1981. Distribution patterns and conservation of eastern Brazilian coastal forest tree species. Brittonia 33:233-245.

OLIVEIRA, R.R. \& LACERDA, L.D. 1988. Contaminação por chumbo na serrapilheira do Parque Nacional da Tijuca RJ. Acta Botanica Brasilica 1:165-169.

PACCALA, S.W., CANHAM, C.D., SAPONARA, J., SILANDER, J., KOBE, R.K. \& RIBBENS, E. 1996. Forest models defined by field measurements: estimation, error analysis and dynamics. Ecological Monographs $66: 1-43$.

POORTER, L. 1999. Growth responses of 15 rain-forest tree species to a light gradient: the relative importance of morphological and physiological traits. Functional Ecology 13:396-410.

RICHARDS, P.W. 1996. The tropical rain forest. Cambridge University Press, Cambridge.

SARUKHÁN, J. 1978. Studies on the demography of tropical trees. In Tropical trees as living systems. Part I (P.B. Tomlinson \& M.H. Zimmermann, eds.). Cambridge University Press, Cambridge. p.173-185.

SHEIL, D. \& MAY, R.M. 1996. Mortality and recruitment rate evaluations in heterogeneous tropical forests. Journal of Ecology 84:91-100.

SHEIL, D., BURSLEM, D.F.R.P. \& ALDER, D. 1995. The interpretation and misinterpretation of mortality rate measures. Journal of Ecology 83:331-333. 
SILVA-MATOS, D.M. \& WATKINSON, A.R. 1998. The fecundity, seed and seedling ecology of Euterpe edulis Mart. (Palmae) in a fragment of semideciduous forest, Brazil. Biotropica 30:595-603.

SILVA-MATOS, D.M., FRECKLETON, R.P. \& WATKINSON, A.R. 1999. The role of density dependence in the population dyanamics of a tropical palm. Ecology 90:2635-2650.

STILL, M.J. 1996. Rates of mortality and growth in three groups of dipterocarp seedlings in Sabah, Malaysia. In Ecology of tropical forest tree seedlings (M.D. Swaine, ed.). Unesco/Pathernon, Paris/Carnforth, p.315-332.

SWAINE, M.D. \& WHITMORE, T.C. 1988. On the definition of ecological species groups in tropical rain forests. Vegetatio 75:81-86.

SWAINE, M.D., THOMPSON, J., AGYEMAN, V.K., KYEREH, B. \& ORGLE, T.K. 1997. Ecology of forest trees in Ghana. ODA Forestry Series 7. University of Oberdeen, London.

VAZQUEZ-YANES, C. \& OROZCO-SEGOVIA, A. 1984. Ecophysiology of seed germination in the tropical humid forests of the word: a review. In Physiological ecology of plants of the wet tropics (E. Medina, H.A. Hooney \& C. Vasquez-Yanez, eds.). Dr Junk, The Hague, p.37-50.
VEENENDAAL, E.M., SWAINE, M.D., LECHA, R.T., WALSH, M.F., ABEBRESE, I.K. \& OWUSU-AFRIYIE, K. 1996. Response of West African forest tree seedlings to irradiance and soil fertility. Functional Ecology 10:501-511.

VELLOSO, H.P., RANGELFILHO,A.L.R. \& LIMA, J.C.A. 1991. Classificação da vegetação brasileira, adaptada a um sistema universal. Fundação Instituto Brasileiro de Geografia e Estatística, Brasília.

WADA, N. \& RIBBENS, E. 1997. Japanese maple (Acer palmatum var. matsumurae, Aceraceae) recruitment pattern: seeds, seedlings, and saplings in relation to conspecific adult neighbors. American Journal of Botany 84:1294-1300

WEBB, E.L. 1999. Growth ecology of Carapa nicaraguensis Aublet (Meliaceae): implications for natural forest management. Biotropica 31:102-110.

WELDEN, C.W., HEWETT, S.W., HUBBELL, S.P. \& FOSTER, R.B. 1991. Sapling survival, growth and recruitment: relationship to canopy height in a neotropical forest. Ecology 72:35-50.

WILKINSON, L. 1997. Systat: System for statistics. Systat, Inc., Evanston.

ZAR, J.H. 1996. Biostatistical analysis. Prentice Hall, New Jersey. 